\title{
MKRN1 wt Allele
}

National Cancer Institute

\section{Source}

National Cancer Institute. MKRN1 wt Allele. NCI Thesaurus. Code C111935.

Human MKRN1 wild-type allele is located in the vicinity of 7q34 and is approximately 27 $\mathrm{kb}$ in length. This allele, which encodes E3 ubiquitin-protein lig ase makorin-1 protein, plays a role in post-translational protein ubiquitination. A fusion of this gene and the BRAF gene may be associated with pilocytic astrocytoma. 